IJOLTL, Vol. 3, No. 1, January 2018

p ISSN: 2502 2326; e ISSN: 2502 8278

Http://ijolt1.pusatbahasa.or.id; Email: ijolt1@gmail.com

Center of Language and Culture Studies, Surakarta, Indonesia

Suhirman, Lalu. 2018. ESP Textbook Evaluation: English for Islamic Learning for College Students. IJOLTL (2018), 3(1): 13 22. DOI:10.30957/ijoltl.V3i1.401.

\title{
ESP TEXTBOOK EVALUATION: English for Islamic Learning for College Students
}

\author{
Lalu Suhirman \\ Cenderawasih University Jayapura Papua \\ Email: lalusuhermanmpd@gmail.com
}

\begin{abstract}
ESP Textbook evaluation has become a necessary practice in the field of teaching, seeking to assist in the choice of the best suitable textbook for a specific context. This article presents an evaluation of English textbook "English for Islamic Learning: for College Students".The researcher identifies how well the textbook meets the students' English learning needs and how much appropriate activities it is presented.The ESP textbook has been evaluated impressionistically which covers the textbook (contents, presentations, and strategies) and student's needs and interests.For this purpose, 20 students and 1 teacher were selected and data were gathered by two questionnaires which were made by Garant (1987). The teacher questionnaire consisted of 10 items and the student version is also consisted of 10 items. An additional component of the study consisted of a student "needs analysis" that was conducted at the same time as the textbook evaluation survey. After analyzing data, it was shown that although the textbook had some drawbacks, especially in terms of language skills, it had met students' needs and interests.
\end{abstract}

Keywords: evaluation, English, ESP, textbook, Islamic learning

\section{BACKGROUND}

Dona Imperial (2008) defines the instructional materials are kind of tools or equipment can help effectively the instructor in theory teaching classroom or in practical assessment - e. g the physical angle swivel coupling, putlog clip for putlog tube fittings - one deteriorated punctured standard in scaffolding elements. Instructional materials are educational resources used to improve students' knowledge, abilities, and skills, to monitor their assimilation of information, and to contribute to their overall development and upbringing. According to Tomlinson (2003) materials development refers to anything which is done by writers, teachers or learners to provide sources of language input in ways which maximize the likelihood of intake. In other words, it also relates to the supplying of information about and/ or experience of the language in ways designed to promote language learning.

Instructional material is needed to evaluate before or on going uses in instructional activities to view the strength or the weakness or the suitability with 
IJOLTL, Vol. 3, No. 1, January 2018

p ISSN: 2502 2326; e ISSN: 2502 8278

Http://ijolt1.pusatbahasa.or.id; Email: ijolt1@gmail.com

Center of Language and Culture Studies, Surakarta, Indonesia

Suhirman, Lalu. 2018. ESP Textbook Evaluation: English for Islamic Learning for College Students. IJOLTL (2018), 3(1): 13 22. DOI:10.30957/ijolt1.V3i1.401.

the syllabus (curriculum), student's and teacher's need. Materials evaluation according to Tomlinson is a procedure that involvemeasuring the value (or potential value) of a set of learning materials. It involves making judgment about the effect of the materials on the people using them, (Tomlinson, 2003:16). Further he states the differences between materials evaluation and materials analysis. An evaluation focuses on the users of the materials and makes judgments about their effect. No matter how structured, criterion reference and rigorous an evaluation is, it be essentially subjective. On the other hand, an analysis focuses on the materials and it aims to provide an objective analysis of them. It asks questions about what the materials contain, what the aim to achieve and what they ask learners to do.

Based on extensive research, Florida has identified three priorities for the evaluation of instructional materials. These priorities are content, presentation, and learning. Content must align with the state's standards and benchmarks for the subject area. Alignment is reflected in correlations of content with curriculum requirements, scope of content, and completeness for use in instruction. Correlations Content alignment refers to the match between the materials and the curriculum. Yalden (1987) suggests the evaluation of materials (modules) should link with the types of curriculum (contextual syllabus, notional syllabus, or semantic syllabus), student, and teacher. Dick and Carry (1985) also generally emphasize the materials evaluation related to curriculum, students, and teachers.

Therefore, materials according Dick and Carry (1985:168) particularly can be evaluated to determine whether (1) adequate motivational materials exist, (2) the appropriate content is included, (3) the sequence is correct, (4) all the required information is available, (5) practice exercise exist, (6) adequate feedback is included, (7) appropriate tests are available, (8) adequate follow-up directions are included for remediation, advanced work, or general progress, and (9) adequate learners guidance is provided to move students from one event or activity to the next.

The textbook material which will be evaluated is an ESP textbook for Islamic College students. The main aspects evaluated on this textbook is impressionistic by using three steps or types introduced by Florida (1985), namely content (curriculum), presentation and learning. These three types cover the component student's need, and teacher's interest related to the textbook. The evaluation also deals with a few sub categories. These are the general appearance, design and illustration, accompanying materials. In addition to impressionistic evaluation, it is also seen the perception of students related to their needs and interest in textbooks introduced.

\section{REVIEW OF LITERATURE}

Textbooks may function as intermediary roles and potential agents for change during educational innovation due to a number of reasons; first textbooks 
IJOLTL, Vol. 3, No. 1, January 2018

p ISSN: 2502 2326; e ISSN: 2502 8278

Http://ijolt1.pusatbahasa.or.id; Email: ijolt1@gmail.com

Center of Language and Culture Studies, Surakarta, Indonesia

Suhirman, Lalu. 2018. ESP Textbook Evaluation: English for Islamic Learning for College Students. IJOLTL (2018), 3(1): 13 22. DOI:10.30957/ijolt1.V3i1.401.

act as a vehicle for teacher and learner training; second textbooks provide a picture of what the change will look like; and third, they provide the psychological support to teachers (Kirkgoz, 2009). As remarked by Richards (2001), good textbooks serve to turn the guidelines in the official government syllabus into a rich source of content. Given the crucial role of textbooks in language teaching program, this study aims to investigate a students' perceptions of the ELT textbooks, and b) the extent to which textbooks function as the agent of change in meeting of curriculum goals and objectives.

Textbooks are commodities, political objects, and cultural representations and, therefore, are the site and result of struggles and compromise in order to determine how and by whom they will be produced, how and by whom their contents will be selected, how and to whom they will be distributed, and how teachers and students will make use of them(Shannon, 2010).

Cunningsworth (1995) and Ellis (1997) have suggested that there are three different types of material evaluation. They argue that the most common form is probably the 'predictive' or 'pre-use' evaluation that is designed to examine the future or potential performance of a textbook. The other types of textbook evaluation are the 'in-use' evaluation designed to examine material that is currently being used and the 'retrospective' or 'post-use' (reflective) evaluation of a textbook that has been used in any respective institution. Grant (1987) also states three stages of textbook evaluation, such as: initial evaluation, detailed evaluation, and in-use evaluation.

Marc and Rees (2009) analyze the content of textbooks as well as teachers' usage of them. Results show author representation in textbooks increasingly resembles students' reading preferences at the expense of selections made by literary experts. At the same time, teachers have increasingly adopted textbooks that regarded students' preferences the most. These trends seem to be the result of changes in the student population rather than teachers' professional characteristics.

Hatoss (2004), presented a model which can be used for evaluating language textbooks in terms of their adequacy in teaching culture and developing intercultural skills. The model is based on theories of culture and theories of language learning. Her model is based on three dimensions: input, method, aims. She opines that a textbook should represent the culture of the target society too and evaluation criteria should also focus on the cultural aspects given in the textbook. Models are necessary to provide a conceptual framework for designing a particular evaluation depending on the specific purpose of the evaluation. "The models differ in many of their details, the decision to choose an evaluation model depends on a few important factors such as the evaluation questions, the issues that must be addressed, and the available resources (Grant, 1989)." Cunningsworth (1984), in his book "Evaluating and Selecting EFL Teaching 
IJOLTL, Vol. 3, No. 1, January 2018

p ISSN: 2502 2326; e ISSN: 2502 8278

Http://ijolt1.pusatbahasa.or.id; Email: ijolt1@gmail.com

Center of Language and Culture Studies, Surakarta, Indonesia

Suhirman, Lalu. 2018. ESP Textbook Evaluation: English for Islamic Learning for College Students. IJOLTL (2018), 3(1): 13 22. DOI:10.30957/ijolt1.V3i1.401.

Materials" also proposed a checklist of questions which summarizes the criteria for evaluation.

There can be different methods of evaluation. McGrath (2002), presents some methods of evaluation in his book 'Materials Evaluation and Design for Language Teaching'. One of the methods he explains is the checklist method, where essential criteria are listed and systematically checked off. Other methods are the impressionistic and in-depth method which means that materials are chosen for thorough examination. McGrath (2002) recommends pre- use evaluation, in-use evaluation and post-use evaluation. This means that the material should not only be evaluated before being used, but constantly while using it as well as after use. McGrath's basic explanation of textbook evaluation concerns the discovery of whether what you were looking for was there. When found, you then need to put a value on your findings. Evaluation implies judgment-making which therefore also means that evaluation is subjective.

Tomlinson (2011), offers a short summary of the history of materials development. He gives two reasons why the interest in materials development increased. One was the realization that by making teachers aware of the process of materials development, it would be easier for them to understand and apply theories of language learning. It would also help teachers to develop personally and professionally. The other reason was the understanding that no course book can be suitable for any kind of learners. Therefore teachers need to be able to evaluate, adapt and produce materials that would be appropriate for their particular class.

Grant (1989) offers one way of finding out whether a book is worth looking more closely is to apply the 'CATALYST' test. A textbook should act as a catalyst in the classroom. Like the catalyst in a chemistry laboratory, it should facilitate change. The eight letters in the word CATALYST represent the eight criteria by which we can decide whether a textbook is suitable for classroom. The words in the mnemonic represent the key questions we should ask ourselves: $\mathrm{C}=$ communication, $\mathrm{A}=$ aims, $\mathrm{T}=$ teachability, $\mathrm{A}=$ available add-on, $\mathrm{L}=$ level, $\mathrm{Y}=$ your impression, $\mathrm{S}=$ student interest, and $\mathrm{T}=$ tried and tested.

To Prabhu (1987) Textbooks are fully specified and pre-constructed materials that provide a certain amount of uniformity in what occurs in many different classes with different teachers and students, which serves the interests of accountability. Sheldon (1988) has offered several reasons for textbook evaluation. He suggests that the selection of an ELT textbook often signals an important administrative and educational decision in which there is considerable professional, financial, or even political investment. A thorough evaluation, therefore, would enable the managerial and teaching staff of a specific institution or organization to discriminate between all of the available textbooks on the market (David, 2001). 
IJOLTL, Vol. 3, No. 1, January 2018

p ISSN: 2502 2326; e ISSN: 2502 8278

Http://ijolt1.pusatbahasa.or.id; Email: ijolt1@gmail.com

Center of Language and Culture Studies, Surakarta, Indonesia

Suhirman, Lalu. 2018. ESP Textbook Evaluation: English for Islamic Learning for College Students. IJOLTL (2018), 3(1): 13 22. DOI:10.30957/ijolt1.V3i1.401.

\section{METHODS}

\subsection{Design}

Descriptive qualitative method has been used for analyzing and evaluating the data. This section discusses subject and instrument used in the study.

\subsection{Subjects}

For the purpose of this study, 20 students and a teacher who were studying and teaching at STAIN Jayapura participated in this study. The teacher had taught this ESP textbook for a year and the students were from low intermediate levels. The age of the students ranged from 18-19 and all of them were studying in the Tarbiyah (Islamic education) department.

\subsection{Instruments}

Observation and questionnaires have been selected as the main instruments of the study because they offer the most economical and reliable means of reaching a decision concerning the relative suitability of the textbook under scope. There were two major issues evaluated from this ESP textbook, which include:

Problem 1: Impressionistic evaluation which involves an overall presentation and analysis of the textbook related to its design, table of contents, distribution of units, lessons and sections in the book.

Problem 2: For gathering data from the participants, two questionnaires were used. These questionnaires were adopted from Grand (1989). The questionnaires were in Linkert check list scales, and the participants were asked to choose among "YES, PARTLY, NO" for each item. The teacher questionnaire consisted of 10 items and the student questionnaire consisted of 10 items, too.

\subsection{Data Collection and Analysis}

Observation data is through reading the textbook as a whole and repeatedly and observing each chapter carefully to obtain impressionic data.The questionnaires in English were administered to the chosen students and a teacher. For collecting data from the students, the researcher distributed the instrument during class time preceded by a brief explanation of the purposeand the nature of the study and if they had difficulty in the interpretation of any item, the researcher helped them to understand the item. For collecting data from the teacher, the researcher distributed the instrument to the teacher and explained the nature and purpose of the study to him. After the collection of the instrument, it was collected for data analysis. The percentage of the teacher and students in each single item were calculated in simple statistics to summarize the teacher's and students' views about the textbook. 
IJOLTL, Vol. 3, No. 1, January 2018

p ISSN: 2502 2326; e ISSN: 2502 8278

Http://ijolt1.pusatbahasa.or.id; Email: ijolt1@gmail.com

Center of Language and Culture Studies, Surakarta, Indonesia

Suhirman, Lalu. 2018. ESP Textbook Evaluation: English for Islamic Learning for College Students. IJOLTL (2018), 3(1): 13 22. DOI:10.30957/ijolt1.V3i1.401.

\section{FINDINGS}

\subsection{Impressionistic}

\subsubsection{Content}

This book aims as an English for Specific Purposes (ESP) for Islamic college students in Indonesia. It seems that from the title and reading text possess nuance in Islamic values, Islamic histories, and Islamic activities. This book is specifically designed to meet the needs of Islamic students in colleges of Islam, public or private Islamic colleges such as: Higher School of Islamic Religious Science or Islamic University (STAIN or STAIS, UIN). The writer has tried primarily organized on the basis of the urgent need for English Islamic reading passages. This ESP textbook is exactly relevant with the goal of English language curriculum at Islamic college students. Whereas one of the objectives of the English curriculum at Islamic colleges is to deliver to the students for comprehending English language skills whereas the syntactic terms possibly related to Islamic word terms. Conversely, to give and provide English knowledge or competency for learners after accomplishing English subject (English lecturing) they can communicate simple English oral or written which is in Islamic nuances.

The contents of this course book correspond closely with the aims the curriculum and the teaching program and also engage with the need of the learners. This course book performs reading selections in accordance with the Islamic values and followed by a few comprehension questions to each passage then continued by discussing basic grammar or structure which completed with some exercises. At least, the contents of this ESP course book for Islamic is mostly relevant with the curriculum or syllabus and suitable to the learning/ teaching situation for Islamic college learners. Even though there are some crucial substances not covered in this course book but it is very valuable to use. As long as the writer taught at Islamic college (STAIN former STAIS) since 2004 up to now, he accidentally found this book at Gramedia book store in Ramayana supermarket on Jalan Perintis Makassar. He was very interested and exited with this book because its colors cover is a little bit peculiar with blue and red which is light white circle like a sickle moon. After reading scanning, he obtained valuable inference to the book that this Islamic course book offers some behind creative instructional activities especially for and English instructor or lecturer. Truthfully admitted, this book is still poor with the variation of exercise activities, but in the evaluator point of view, this is a kind of corner stone or step stone for English teacher or lecturer to develop her/his creativity to enrich what is not exist in this Islamic ESP course book.

As the evaluator of this Islamic ESP course book, it still does not cover all students' need yet particularly the vary of exercise activity learning English, but I myself view that, this is a smooth way for the teacher or lecturer to demonstrate her/his knowledge, competence or experience in form of developing various instructional activities. This course book might not be able to represent the entire 
IJOLTL, Vol. 3, No. 1, January 2018

p ISSN: 2502 2326; e ISSN: 2502 8278

Http://ijolt1.pusatbahasa.or.id; Email: ijolt1@gmail.com

Center of Language and Culture Studies, Surakarta, Indonesia

Suhirman, Lalu. 2018. ESP Textbook Evaluation: English for Islamic Learning for College Students. IJOLTL (2018), 3(1): 13 22. DOI:10.30957/ijolt1.V3i1.401.

student's need and teacher's teaching strategies but again this course book will be very valuable on the hand of creative English teacher or lecturer.

\subsubsection{Presentation}

Paying attention to physical face of the course book is quite interesting with the combination of red and blue and added with light white circle is like a sickle moon. This Islamic ESP course book seems that can be used by the learners and lecturers. It means that, there is no discrimination package of book in terms of student's book, teacher's book, workbook, or cassettes. The content organization of the Islamic ESP textbook sequencing consists of reading selections with the nuance topics of Islamic religion, and in each passage or selection is provided with a few comprehension questions related to the content of the text. Other interesting variation in the text is included with the verses of Qur'an written originally in Arabic. This exactly makes the Islamic ESP textbook more attractive. Moslem students will be also more interested to read the text after glancing the orthography of Arabic and English.

After the presentation of reading text and its questions, it is specifically discussed grammar and exercises related to the substance of grammar. Conversely, the Islamic ESP textbook just present or discuss reading skill and grammar. The presentation complexity of grammar materials seems that it follows the pedagogic standard, whereas it begins with the low or easy level and up to difficult level. In each of activity, it is preceded with the clear instruction. All instructions are in English. This textbook might be suitable used for individual because of it is facilitated with many exercises especially for grammar. This textbook does not provide vocabulary, pronunciation, listening, speaking, and writing.

\subsubsection{Strategies}

Learning strategy applies in this text book is very limited. It just directs readers to read and answer a few comprehension questions, direct learners to do exercises related to grammar exercises. There is lack of lecturing or unclear explanation delivering examples for each focus of grammar. This textbook will not be useful for individual learning, it is needed a creative English teacher to complete poor strategies used in this book.

\section{2 Teacher's and Students' Perception}

The results of teacher questionnaire related to the activities part showed that the the teacher put himself in the neutral part but he agreed that the textbook's activities could be modified and supplemented easily. On the other side the students thought that the textbook provided a sufficient balance of activities and the activities encouraged communicative and meaningful practice and they also believed that the activities promoted creative, original, and independent 
IJOLTL, Vol. 3, No. 1, January 2018

p ISSN: 2502 2326; e ISSN: 2502 8278

Http://ijolt1.pusatbahasa.or.id; Email: ijolt1@gmail.com

Center of Language and Culture Studies, Surakarta, Indonesia

Suhirman, Lalu. 2018. ESP Textbook Evaluation: English for Islamic Learning for College Students. IJOLTL (2018), 3(1): 13 22. DOI:10.30957/ijolt1.V3i1.401.

responses. One possible reason for this rate of agreement is the teaching methodology and the ESP textbook which is taught in specipic Islamic institutions. Most Indonesian classrooms are teacher-centered and learning, if any occurs, is the result of drilling and memorization and the English textbooks follow audiolingual method. Most of students agreed with the religious topics because they are appropriate with the topics learned in other subjects, such as the basic of faith in Islam, the fitrah (clean) term, the deen (religion) of Islam, prohibition on pork, etc.

\section{DISCUSSION}

The content of this Islamic ESP textbook is quite relevant with the curriculum used in the Islamic colleges. The objective of the English curriculum in accordance with the learner's need is integrated in this book. This book is still poor with the variation of exercise activities, but this is as fruitful chance for a creative teacher to develop his teaching strategies. He or she can rise contextually topics that do not exist in the text book. Johnson says that the teacher initially involves with the contextual teaching and learning presumably because common sense and experience told them that uniting the abstract and concrete, thought and action, concept and practice would help all students learn academic material (Johnson, 2002).

This Islamic ESP textbook presentation is limited on discussing 'reading and grammar or structure'. Each of which followed by exercises but the exercises are not vary. Therefore, this book is appropriate and able to serve as learning materials for both students and teachers. It can serve a primary source of knowledge content, present specific views about the nature of Islamic practices, and how linguistic knowledge is developed. Even though the content of the text book only consists of reading passage and structure exercises but it can also serve as a primary influence on how English teachers/lectures should teach ESP particularly related to Islamic cultures. Through reading topics nuance in Islamic terms existed in this textbook, they will encourage learners to struggle for finding common terms between learner's mother tongue and the target language.

It is admitted that there are many components should cover in this textbook such as, guiding to do reading activities (scanning or skimming), discussion, viewing vocabularies, pronunciation, etc., but it is clear that, the instructional materials containing of this textbook that align with curriculum standards and that take into account what is known about the teaching and learning of English.

Teaching and learning strategies are still very poor in this textbook. It just presents reading passage and structure exercises. This textbook even it can be used by the students individually but they still need guidance from English teachers to develop some learning strategy activities. The ideal textbook, it should provide contextualizing elements (collaboration, role play, case studies) that 
IJOLTL, Vol. 3, No. 1, January 2018

p ISSN: 2502 2326; e ISSN: 2502 8278

Http://ijolt1.pusatbahasa.or.id; Email: ijolt1@gmail.com

Center of Language and Culture Studies, Surakarta, Indonesia

Suhirman, Lalu. 2018. ESP Textbook Evaluation: English for Islamic Learning for College Students. IJOLTL (2018), 3(1): 13 22. DOI:10.30957/ijolt1.V3i1.401.

permit for multiple and varied perspectives. Contextualizing also helps link ideas to prior knowledge. Learners bring experience that is unique to their cultural and ethnic backgrounds, especially on Islamic nuances. In addition, motivation and decision making should be built in to the materials being developed. Otherwise, based on the lack of strategies or methods covered in this book but for creative teachers/lecturers will see this chance as the greatest flexibility and encourages the development of material strategies s that are focused on learner needs.

For the other items of the part of the questionnaire, the majority of the respondents were in agreement position. For example, they agreed that the language used was at the right level for the students, the grammar points were presented with brief and easy examples, and the language functions exemplified English that the students would be likely to use. They also liked and agreed with the contextual topics about religion. The teacher and the majority of students thought that the textbook did not represent a diverse range of registers and accents. Most of the students need the presentation of language skills and language components should be presented integrated.

\section{CONCLUSION}

In evaluating instructional materials (textbook), the instructor should begin by analyzing what the learner should know at the end of the course and how that learning will be demonstrated. In addition, the instructor should also consider the relevant of instructional materials with the curriculum/syllabus content and the skills the teachers and learners possess. Since the materials are being evaluated for skills within the interpersonal domain, the materials should permit for peersharing, group activities, and interpersonal interactions. The materials are expected to target communication in English by presenting all language components and target language skills. The teacher felt that the ESP textbook for Islamic learning was suitable for the language- learning aims and he/they would choose to use the textbook again and it also raised students' interest in further English language study.

\section{SUGGESTIONS}

In the instructional process, teachers or educational personnel and students cannot be separated by the using of instructional media. That's why, the selection of media is another important component to address when developing instructional materials for the interpersonal domain. Certain media permit for different learning opportunities. For example, role playing encourages working together and provides the learners with an opportunity to give and receive feedback. However, like any media we may select, there are considerations we need to keep in mind. While role playing does have benefits, it can be difficult to implement in large classroom situations. The chart organizer within the lesson is 
IJOLTL, Vol. 3, No. 1, January 2018

p ISSN: 2502 2326; e ISSN: 2502 8278

Http://ijolt1.pusatbahasa.or.id; Email: ijolt1@gmail.com

Center of Language and Culture Studies, Surakarta, Indonesia

Suhirman, Lalu. 2018. ESP Textbook Evaluation: English for Islamic Learning for College Students. IJOLTL (2018), 3(1): 13 22. DOI:10.30957/ijolt1.V3i1.401.

designed to assist the teacher/ lecturer with the process of selecting the appropriate media for his/her learners particular needs.

\section{REFERENCES}

Cunningsworth, A. (1995). Choosing Your Coursebook, Oxford: Heinemann.

Dick, W. \& Carey L. (1978). The systematic design of instruction. Illinois: Scott \& Co. Publication.

Ellis, R. (1997). The Empirical Evaluation of Language Teaching Materials. ELT Journal. 51(1), 36-42.

Florida Department Education. (2008). Priorities for Evaluating Instructional Materials: Research Update. Florida Department Education.

Hatoss, A. (2004). A model for evaluating textbooks. Volume 39.

Imperial, Donna. 2008. Preparation and Evaluation of Instructional Materials. Presentation Transcript, http://www.slideshare.net/kyunnashi/preparationand-evaluation-of-instructional-materials-14965099, cited on 2/09/2017.

Johnson, Elaine, B. 2002. Contextual Teaching and Learning. United Kingdom: Corwin Press.

Kirkgoz, K. 2009. Evaluating the English textbooks for young learners of English at Social and Behavioral Sciences 1 (2009) 79-83

Marc V., \& Rees, K. (2009). Literary education curriculum and institutional contexts: Textbook content and teachers' textbook usage in Dutch literary education, 1968-2000. Poetics, 37(1), 74-97

McGrath, I. (2002). Material Evaluation and Design for Language Teaching. Edinburgh: Edinburgh University Press.

Prabhu ,N.S. (1987). Second Language Pedagogy. Oxford: Oxford University Press.

Richards, J. C. (2001). The role of textbooks in a language program. Retrieved September 2, 2017, from http://www.professorjackrichards.com/pdfs/roleof-textbooks.pdf

Shannon, p. (2010). Textbook Development and Selection. International Encyclopaedia of Education (Third Edition).

Sheldon, L. (1988). Evaluating ELT textbooks and materials. ELT Journal, 42 (4), 237-246.

Tomlinson, Brian. (2003). Evaluation and Adaptation of Materials. (Ed.). Developing Materials for Language Teaching. Tomlinson, B. London: Cromwell Press.

Yalden, Janice. (1987) Principles of Course Design for Language Teaching. New York: Cambridge University Press. 